\title{
The Perfection Concept in the Epistle To the Hebrews *
}

\author{
Alvin A. Ahern
}

\section{INTRODUCTION}

The idea of perfection has long intrigued the moral philosopher as well as the theologian. Plato's ethics envisaged the final attainment by man of moral perfection through eros. Immanuel Kant's postulate of immortality was based on the idea that moral value is potentially complete. Some of our contemporaries, for instance, Wilbur Marshall Urban, stress a teleological ethics that contemplates completeness in full self-realization.

Perhaps the moral theorist generally has thought beyond his own time, but he has also rendered a practical service for his time. Though the practical interests of politics and economics, for instance, often try to ignore moral requirements, the ethical thinker is generally on hand to show that eventually they must find that any security they have is a moral security.

Recently science seems to have shocked most of the thinking world into a realization that humanity's problem today is essentially a moral problem. Perhaps it is not rash to infer, therefore, that the confusion of our post-war world is primarily a moral confusion. If this is true what can Bible instructor's do to help correct this situation?

They can do what many of them/reomicoll, writing of the Epistle to doing. They can help an otherwise literate world turn again to the scrip- for getober, 1930, on the eve of the tures with eyes to see and ears to hear recent world conflict, declares, "The - nessage of this unknown, but clear.

*Reprinted from THE JOURNAL OF BIBLE

AND RELIGION, Vol. XIV, No. 3, August, IVestcott, Brooke Foss: The Epistle To The

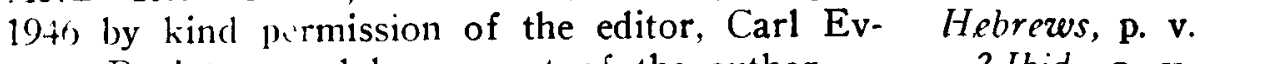

crett Purinton, and by consent of the author 
sighted, first century leader was never more needed than it is today."

The present study foregoes treatment of many interesting and rewarding topics and concerns itself with a somewhat neglected emphasis in the epistle, viz., the concept of perfection and its ethical implications.

\section{The IDEA of teleiosis}

Mr. Westcott suggests that "The idea of teleiosis, consummation, bringing to perfection, is characteristic of the Epistle."3 Christians have often if not generally faltered at the thought of perfection. It is awe-inspiring, as awe-inspiring as the atomic bomb. Perhaps it even more real and more weighted with significance.

In the epistle the Greek word teleios, ordinarily translated perfect or perfection, appears in one form or another sixteen times. The whole family of words connected with teleios is found here: teleios $(5: 14$, $9: 11)$, teleiotes ( $6: 1$, elsewhere only in Col. $3: 14$ ), teleioun referring to Christ $(2: 10 ; 5: 9 ; 7: 28)$ and to men ( $10: 14 ; 11: 40 ; 12: 23)$.

The noun teleiotes is quite common in classical Greek. According to the Liddell and Scott lexicon it "means having reached its end, finished, complete. . . . It is used in reference to animals as full-grown, to persons as complete or accomplished." Thayer says it means "brought to its end, finished, wanting nothing necessary to completeness; perfect."

In the epistle the idea is related particularly to Christ and to his followers. First, he himself is "perfect. ed" as indicated in the three passages. $2: 10 ; 5: 9 ;$ and $7: 28$. Second, he 60 rogic In his Fondren Lectures of 1945 . fects" others, noted in three more spe recently published, Edgar S. Brightcial passages, $10: 14 ; 11: 39,40$; $12 ; 23$. man emphasizes the distinction beThe witer also seeks to showe that tween an ideal and a value, pointing whereas man should be perfect (514; out that an ideal is not a value but a $6: 1)$ he could not become so under the goal. A value is the goal attained or

3 Westcott, Op. cit., p. 63.
Old Covenant provisions $(7: 11,19$; $9: 9 ; 10: 1)$.

Space here permits only a summary of a rather extended investigation of these various passages. The whole argument leads to the conclusion that:

(1) In spite of sin God's purpose and plan for man's moral perfection is ultimately and effectively achieved through Christ as Redeemer.

(2) The writer also holds that in order for Christ to become the Saviour He must follow the tedious and painful process of encountering and overcoming sin at every possible point in human experience.

(3) Furthermore, the perfection of the believer is a sort of paradox. Though perfect in Christ, his achievement is a continuing process. The teaching of this phase of the epistle might well be thought of as the "perfcetion paradox."

\section{The Standard for Man}

In outlining these provisions of redemption the author indicates God's standard or goal for man. Furthermore, he reasons that this standard is within reach and that responsibility for its attainment is upon man himself. In chapter two, verses six throvgh eighteen, the standard is presented and Christ is shown to have met fully all specifications and in so doing has made it possible for every man to do the same. Elaboration of this point must also be omitted from this report. But it should be noted that right here in this second chapter there seems to be suggested a metaphrsical basis for a teleological ('hristian ethics of self-realization. the extent of its attainment. In HehreYYS $2: 6-18$ we see man's exalted 
goal or destiny. But we see more. We see Jesus as Son of Man attaining that ideal. That is value. And for us that value, according to the author of the epistle, seems to lie in the fact that his accomplishment makes it possible for all men to achieve in like manner through Him. One of the chief pur. poses, if not the chief purpose, of this epistle, therefore, seems to be to show that though the Old Covenant under the Law could not free man from the power and condemnation of sin, the "more perfect" covenant through Christ makes victory over sin, as well as freedom from a. sense of its guilt, a present and continuous reality in the life of the believer. Jesus Christ is at once man's Ideal and man's Value. Through man's identification of himself with Christ the moral quality of Christ's own being is imparted. The writer of the epistle cites Jesus as the perfect embodiment of God's ideal for man and concludes that through this "perfected" One all men may find moral completion a present and at the same time a progressive reality.

Thus through the use of the wordfamily of teleios and a few related terms the author seeks to show that the Perfect Offering ( $7: 26-28 ; 9: 14$, $15,26 ; 10: 10)$ of the Perfected One $(2: 10 ; 5: 9 ; 7: 26-28 ; 10: 10)$ Perfects the Bclierer $(6: 1 ; 7: 25 ; 9: 14,15 ; 10$ : $10,14 ; 12: 23)$.

\section{The Perfection Paradox Clarified}

In his comprehensive work, The Meaning of God in II uman Experience, William Ernest Hocking, Emeritus Professor of Philosophy at Harvard University, proposes an idea that throws light on this discussion ando Gepurpose.

deserves fir more attention the perfect, striving for perfection! has received. He speaks of religion as $\mathrm{It}$ sounds paradoxical. Perhaps it is. "anticipated attainment." Savs he, Have not the holiest saints been the in comparing art and religion, we may now say, is the present attainment in a single experience of those objects which in the course of nature are reached only at the end of infinite progression. Religion is anticipated attainment. 4

\section{On the other hand he shows that,}

Whatever may be the nature of that anticipation of all attainment, genuine religion is not inclined - as far as hard work goes - to take advantage of its advantage. If being in the world it is not of the world, it is none the less with the world and for it-in brief in for it, and with no luss of power. This is an extraordinary attainment which one must still labor forever to possess: but just this paradox is inherent in the religious consciousness. 5

In this same connection Hocking also notes that,

In time my moral task will never be finished, for my imperfection is infinite and my progress by small degrees; but religion calls upon me to be perfect at once even as God is perfect, and in reigion somehow I am perfect. 6

This same idea also seems to be illustrated by st. Paul in Philippians, chitpter 3 , verses $12-15$.

Not that I have already obtained, or am already made perfect (teteleiomai): but I press on, if so be that I may lay hold on that for which also I was laid hold on by Christ Jesus. Brethren, I count not myself yet to have laid hold: but one thing I do, forgetting the things which are behind, and stretching forward to the things which are before, I press on toward the goal unto the prize of the high calling of God in Christ Jesus. Let us therefore, as many as are perfect (telcioi) be thus minded.

In one instance he considers himself to be perfect, complete, mature in Christ, in another as not being perfect. He seems to say, in harmony with the present reality, is something for which he must strive continually with single viriter to the Hebrews, that his perfection, though in a very true sense a

4 Hocking, William Ernest, The Meaning of

Art is long; religion is immediate. The attaingu God in Human Experience, p. 31. ment in every art is future, infinitely distant; the 5 I bid. p. 32. (Second italics are my own.) attainment of religion is present. BE Religion, 
first to declare their constant need of holiness, perhaps just as Socrates insisted that he knew nothing, though declared by the Oracle at Delphi to be the wisest man in Athens?

While emphasizing the experience of inner perfection through faith the author of the epistle recognizes that the perfecting process continues as long as life itself. The Christian is able to make progress in the direction of the ideal goal of moral perfection simply because, through faith in Christ, he actually experiences Christ's moral perfection in kind, though not in degree. And though a man may be becoming progressively more perfect, Kant was probably right in a sense, when he conceived of man's moral endeavor as an eternal thing.

The author of our epistle makes this progress in perfection particularly explicit in the eloquent benediction at the close of the letter.

Now the God of peace, who brought again from the dead the great shepherd of the sheep with the blood of an eternal covenant, even our Lord Jesus, make you perfect in every good thing to do his will, working in us that which is well pleasing in his sight, through Jesus Christ; to whom be the glory for ever and ever. Amen.7

He prays that the inner perfection of his readers may be externalized through everything they do. Interestingly, here the word translated "perfect" is not a form of the verb teleious, but is hatartisai, which is the first aorist optative active of the verb katartizo. It is a combination of kata, which here denotes "in succession, in course," and artios, which means "entirely suited; complete in accomplishment, ready." It would appear that the writer has employed this compound word to emphasize the thought of fection being achived in fection being achieved in the suceess failure to measure up to it. But have ive experiences of life, "in every good they been conscious enough of a presthing to do his will." Thus the para- ent inner moral completeness in an dox continues. He who is morally experience suggested as possible by perfect in Christ through faith in this sufficient atonement for sin must go on in his endless quest for perfection in Christian living.

\section{Possibilitites of Further DEVELOPMENT}

Dr. W. E. Sangster, an English writer, in his recent book, The Path to Perfection (1943), quotes from an address by Dr. R. W. Dale in Carrs Lane Chapel, Birmingham, England, July 27, 1879 . The distinguished divine and educational reformer was attempting a dispassionate appraisal of John Wesley's influence. Among other things Dr. Dale declared:

There was one doctrine of John Wesley's-the doctrine of perfect sanctification-which ought to have led to a great and original ethical development; but the doctrine has not grown; it seems to remain just where John Wesley left it. There has been a want of the genius or the courage to attempt the solution of the immense practical questions which the doctrine suggests. The questions have not been raised-much less solved. To have raised them effectively, indeed, would have been to originate an ethical revolution which would have had a far deeper effect on the thought and life-first of England, and then of the rest of Christendom-than was produced by the Reformation of the sixteenth century. 8

It is my personal belief, after a rather careful study of the Epistle to the Hebrews during the past ten years, that this concept of perfection, as there presented, suggests a metaphysical basis for a teleological Christian ethics of self-realization whose social implications are far-reaching.

Is it possible that ('hristians might exert a greater moral impact on the life of today if they more nearly real. ized in their own experience the possibilities of the "perfection paradox"? Rerhaps believers have always been 
Dr. Hocking's theory of "anticipated attainment"? Might not such an experience afford a moral dynamic and resourcefulness that would enable man to win his individual and social struggle with the problems of evil? Is it failure at this point that is responsible chiefly for the recurring indictment that Christianity is not "practical"? Is (hristianity being really (or realistically) practiced by its professed followers?

In this day of breath-taking discovery in the fields of the sciences perhaps there can be found a frame of mind that is prepared not only to entertain but to demand a solution of our moral problems in terms of this "perfection paradox," which appears to characterize the Epistle to the Hebrews. Dr. Sangster seems to have been in such a frame of mind when in concluding the study mentioned above, he declares,
To believe that the human heart can be cleansed from sin (experience moral perfection) is a bold, big thing to believe, and we have protested against any easy assumption that it has been done because this is fraught with dreadful dangers, not the least of which is a subtle discouragement against being honest with oneself. But the opposite conviction, so it seems to the writer, is not less terrible. 9

The unmodified core of this statement is especially provocative. "To believe that the human heart can be cleansed from sin is a bold, big thing to believe ... But the opposite conviction . . . is not less terrible."

If John Wesley was on the right track in his doctrine of perfection, and the Epistle to the Hebrews seems to suggest that he was, surely it is time this doctrine received more serious consideration with a view toward its future development and toward its enlarged social application.

9 Ibid., p. 190. (Parenthesis and italics are $\mathrm{my}$ own.)

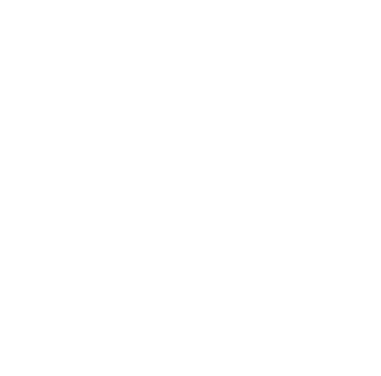

